\title{
PRODUCTIVITY ENHANCEMENT OF STEPPED SOLAR STILL INTEGRATED MEMS LIGHT SENSORS FOR SOLAR TRACKER
}

\author{
ALI. F. MUFTAH \\ Department of Mechanical Engineering, College of Mechanical Engineering Technology, Benghazi,Libya \\ Email: ali.f.muftah@ ceb.edu.ly, ORCID: https://orcid.org/0000-0001-7133-3118
}

\author{
A R T I C L E I N F O \\ Article history: \\ Received 2019-12-08 \\ Accepted 2020-12-20 \\ Available online 2020-12-20 \\ keywords \\ Solar still \\ MEMS light sensors, \\ solar tracking
}

\begin{abstract}
A B S T R A C T
Water is life, and the threat of unsustainable means of potable water supplies has led to the reviews of various renewable energy sources to create a cleaner and more efficient solution for potable water supply. The aim of this study is to present a way in which the efficiency of stepped solar still can be increased. It is to increase the efficiency of solar still by increasing the amount of time that the solar still is directly perpendicular to the sunlight. The MicroElectro-Mechanical Systems (MEMS) light sensors for solar tracking are used to enhance the productivity. The results obtained indicate that the use of MEMS light sensors for solar tracking are used to makes a solar still to be predictable and it equally increases its efficiency in terms of distillate yield and overall performance.
\end{abstract}

\section{INTRODUCTION}

Water is life, and the threat of unsustainable means of potable water supplies has led to the reviews of various renewable energy sources to create a cleaner and more efficient solution for potable water supply (Cooper, 1969). Various modular technologies existed, in which potable water can be produced, but these have proved to be quite expensive as large and very complex designs are involved. Because this problem is prevalent in the world's poorest countries, there is need for the technology to be simple in design, affordable and sustainable (El-Sebaii, 2004).

Conventional solar stills are one method of supplying potable water through using a renewable and free energy source. The solar still is point-of-use technologies that have been proven to remove pathogens, heavy metals and reduce salinity (Hamdan, et al., 1999). Despite the fact that this technology can provide a cheap source of potable water they have the disadvantage that they are on average only $30 \%$ efficient and require $2 \mathrm{~m}^{2}$ to provide for one person's daily needs.

The solar stills have often been used in the tropics where there is abundant supply of solar energy (Tiwari et al., 2003). In this study, a basin-type solar still was designed to investigate the effect of sun tracking in the performance of conventional solar still using actual environmental conditions.

Basically, the still consists of a black-lined shallow basin of saline water enclosed by a transparent cover with sloping sides. Solar radiation passing through the transparent cover is absorbed by the brine and the black basin liner. This radiation is changed to heat by absorption, which serves to warm the brine.
The warm brine partly evaporates and humidifies the air above the surface, thereby reducing the density of the air and causing it to circulate upward. The moving air comes in contact with inner surface of the relatively cool transparent cover, and part of the humidity condenses thereon (Tanaka and Nakatake, 2006).

The liquid condensate forms a film and flows to the base of the cover, from where it drips into the condensate trough and is conducted to the outside of the enclosure. The cooled air returns to the surface of the warm water to repeat the process of humidification. The circulation of air is thus due entirely to free convection. Many adaptations have been made to the solar still design to improve the efficiency, however not so much attention has been paid to sun tracking. This study will investigate the use of sun tracking to improve the potable water yield from a conventional solar still.

\section{PROPOSED DESIGN}

Figure 1 illustrates the schematic diagram of the proposed stepped solar still after modification. As shown in the figure, internal \& external reflectors, external condenser and fins are used to enhance the absorptivity, condensation and evaporation processes inside the solar still.

The width and length of the internal and external reflectors are $(0.6 m \times 2 m),(0.05 m \times 2 m)$ respectively. External condenser made up from galvanized iron with dimension $(0.4 m \times 2 m)$. Then to increase the exposure area, the basin plate was redesigned with five fins with a size of 2 $m \times 0.035 m \times 0.001 \mathrm{~m}$, and the sun tracking system with MEMS light sensors was integrated to solar still. 


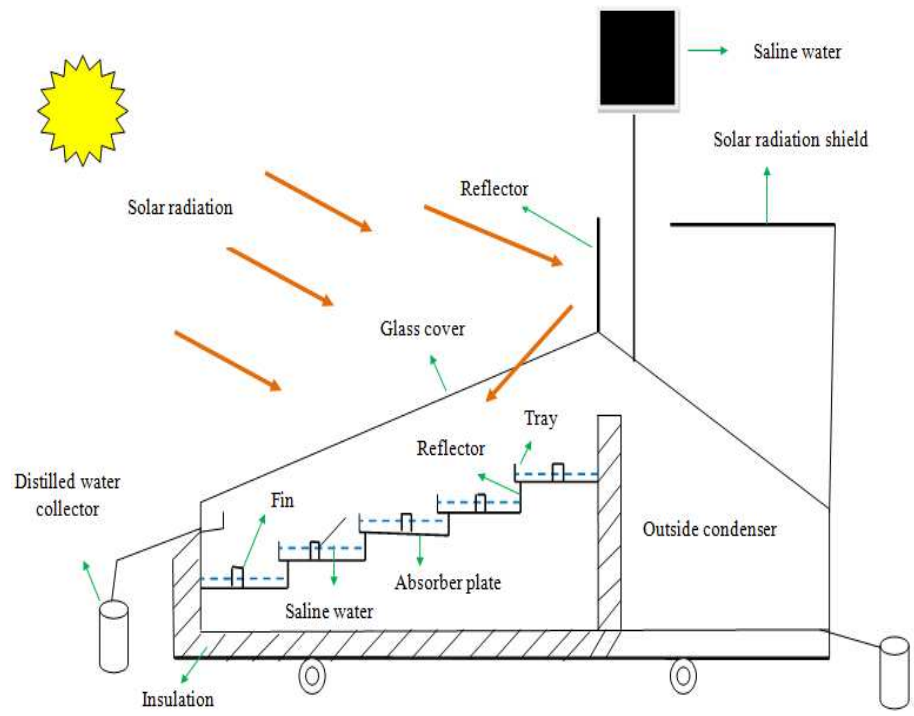

Figure 1. Schematic diagram of the proposed modified stepped basin solar still.

Sun Tracking mechanism is a device incorporated into a solar still which follows the movement of the sun across the sky with the aim of ensuring that maximum solar irradiance is transmitted through the glass cover of the still into the basin and is absorbed by the brine from sunrise to sunset, throughout the day (Figure 2).

The sun tracking mechanism is grouped into two types, the single axis and the double axis models. The single axis is usually on a horizontal axle or vertical axle depending on the region of use and application. The horizontal is used in the tropics where the sun is very high at midday, but with shorter days while the vertical is used in high latitudes where the sun is slightly high, but with very long summer days. The double axis sun tracking mechanism has both a horizontal and vertical axle so, can be deployed anywhere in the world.
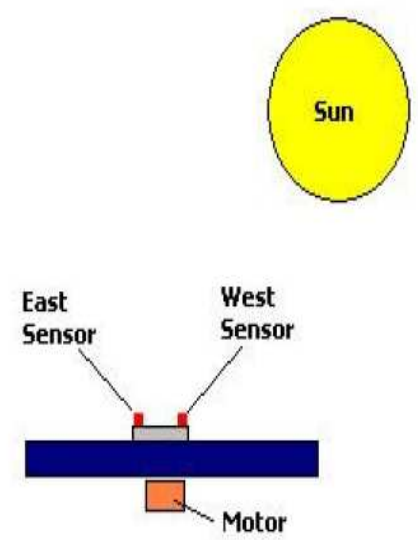

Figure 2. A schematic diagram of a simple sun tracking mechanism.

\section{RESULT AND DISCUSSION}

Figure 3 presents comparisons between variations of hourly productivity of the stepped solar still before and after modification. The hourly productivity is seen to increase dramatically during sunshine hours when the stepped solar still modified is used. The maximum values of hourly productivity of the fixed still and tracked still are found to be 0.18 and 0.13 $\left(\mathrm{kg} / \mathrm{m}^{2} \mathrm{~h}\right)$ respectively. Therefore, it is seen that the daily productivity of the stepped solar still with track is higher than that of the stepped solar still without track by $19 \%$.

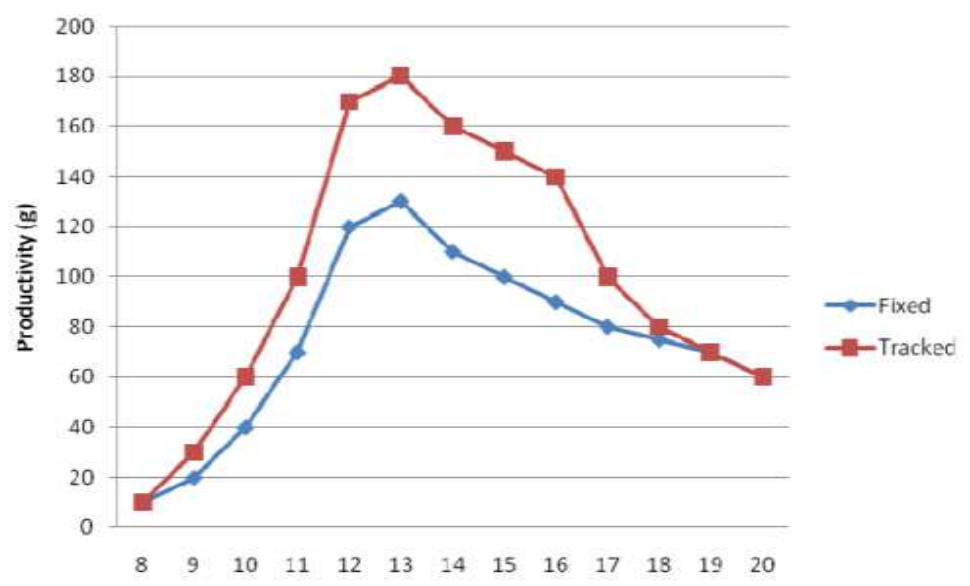

Figure 3. Hourly Production for both the fixed still and tracked still.

\section{CONCLUSION}

From the results obtained, it is inferred that the use of MEMS light sensors for solar tracking are used to makes a solar still to be predictable and it equally increases its efficiency in terms of distillate yield and overall performance. Tracking system was also found be of huge assistance and value, having been used in the past to increase the power output of PV systems.

\section{R E F E R E N C E S}

Cooper, P.I. Digital simulation of transient solar still process, Solar Energy 12. 313-33, 1969.

El-Sebaii, A.A. Effect of wind speed on active and passive solar stills, Energy Conversion and Management 45; 1187-1204. 2004.

Hamdan, M.A., Musa, A.M., Jubran, B.A. Performance of solar still under Jordan climatic conditions, Energy Conversion and Management 40; 495-503, 1999.

Tiwari, GN., Singh, H.N., and Tripathi, R. Solar Energy, 75: 367, 2003.

Tanaka, H., and Nakatake, Y. Theoretical analysis of a basin type solar still with internal and external reflectors. Desalination 197: 205-216, 2006. 